\title{
An Analysis of the National Legislation in Terms of Inclusive Education in Turkey
}

\section{Tansel Yazicioglu}

Nevsehir Hac1 Bektas Veli University, Special Education Department, Turkey

\section{Doi:10.19044/ejes.v7no2a4 URL:http://dx.doi.org/10.19044/ejes.v7no2a4}

\begin{abstract}
Legal arrangements about the special education carried out in Turkey during the 1980's are not sufficient. One of the significant advances in this regard is the law on children with need of special education numbered 2916 which came into effect on 12 October 1983. Also, there are legal regulations about the inclusive educational practices. The aim of this study is to describe and analyse the legal regulations on inclusive education in Turkey in the period of 1983-2020. In the study document analysis which is part of the qualitative research methods is employed. The findings of the research show that there have been different circulars about inclusive education at different time preriods and with different content. The findings of the research also show appropriate integration models for the education of children with special needs will be adopted and implemented at special education schools and institutions. These statements indicate the expanded the rights of children with special needs to education.
\end{abstract}

Keywords: Inclusive, fundamental rights, children with special needs.

\section{Introduction}

During the past 150 years there have been significant changes in the education of children with special needs. Changes in the understanding and views about the education of these children have led to the changes in the roles of schools in relation to their education. One of the results of such changes is that these children began to be educated in inclusive education instead of isolated manner (Kearnay, 2011). Inclusive education was first defined in terms of human rights (Daniels \& Garner, 1999) and therefore, included in the human rights declaration (Artiles ve Dyson, 2005). Inclusive education is a specific educational process which improve learning and cultural and social involvement and at the same time reduce exclusion of the children with special 
needs as well as which meet the needs of all students (United Nations Educational, Scientific and Cultural Organization [UNESCO], 2005).

During the 1970's inclusive education practices began to be implemented in the USA and over time, such practices have become widespread being included in the educational systems of many countries (Organisation for Economic Co-operation and Development [OECD], 1995). Countries changed their legislation, policies and practices to allow the children with special needs to be educated at the same school with their peers. Such changes were also made in Turkey. In 1983 through the law numbered 2916, "Law on Children with needs of special education", inclusive education in Turkey was started. In 1997 a decree law on special education was passed which is numbered 573. Through this decree law pre-school education was made compulsory to the children with special needs. It also set the standards of special education at the levels of primary education, secondary education, higher education and general education. Educational system in Turkey is based on the article 42 of the constitution. It states that noone can be deprived of the right to education and learning and that primary education is compulsory and free of charge for all citizens and is delivered at public schools (Constitution of the Republic of Turkey, [T.C.], 1982).

It can be said that special education policies and legal regulations that guide these policies are an important tool for individuals with special needs to achieve all their human rights, especially their right to life and education, and to solve their existing problems. The World report on disability 2011 by the World Health Organization states that educating the children with special needs with their peers at the same school is much more cost-effective and contributes to reduce discrimination against these children. Inclusive education is closely related to the school culture of accepting differences and of considering education as a human right. The goal of inclusive education is to meet the needs of all children (Loreman, Deppeler and Harvey, 2011; UNESCO, 2012).

Legal arrangements about the special education carried out in Turkey during the 1980's are not sufficient (Eripek, 2005). One of the significant advances in this regard is the law on children with need of special education numbered 2916 which came into effect on 12 October 1983 . The fourth article of this law which is entitled basic principles of special education states "Every child in need of special education benefits from special education services regardless of the type and degree of their disability." In the same article it is also stated "Necessary measures are taken to educate children in need of special education, whose conditions and characteristics are appropriate, with their normal peers at schools and educational institutions that are originally opened for the education of children with no such needs." This statement is also the official commencement of the inclusive education in Turkey. 
In Turkey the number of inclusive students is increasing each year. Based on the data published by the ministry of National education the total number of inclusive students at primary schools, secondary schools and high schools is 173.117 in the school year of 2013-2014. Of them 152.485 are primary and secondary students. The number of those at high schools is 20.632 'dir (MONE, 2014). The data of the ministry for the period of 20172018 show that there were a total of 257.770 inclusive students. Of them 2.601 were pre-school students, 105.098 were primary school students, 108.753 were secondary school students and 41.318 high school students (MONE, 2018). Its data for the period of 2018-2019 indicate that the number of inclusive students is 295.697. Of them 1.260 were pre-school students, 115.556 were primary school students, 130.624 were secondary school students and 48.257 high school students. Based on these data it can be stated that the number of inclusive students has been increased each year which can be considered as a reflection of the adoption of a more comprehensive education understanding in Turkey.

As stated earlier there are legal regulations about the inclusive educational practices. However, such legal regulations have been rarely studies in Turkey (Yilmaz and Melekoglu, 2018; Yazicioglu, 2020). Yilmaz and Melekoglu (2018) described the related laws and egal arrangements about inclusive education in Turkey and European countries. More specifically, the study focused on the inclusive educational practices in Turkey, United Kingdom, Sweden, Denmark, Spain, Greece and Lithuania and concluded that there are serious problems in such activities although each activity is based on a certain law. Yazicioglu (2020) analysed the views of the school principals in regard to the laws about inclusive education. They reported that some of these laws should be updated. In addition, the study concluded that there are some problems in implementing these laws. It can be said that these regulations guide inclusive education practices and have important effects on these practices. The analysis of these legal regulations may guide the future policies and laws. Therefore, the aim of this study is to describe and analyse the legal regulations on inclusive education in Turkey in the period of 1983-2020. In parallel to this aim the study deals with the question of which legal regulations on inclusive education in Turkey in the period of 1983-2020 have been developed and how inclusive education has been conceptualized and implemented within this legal framework. 


\section{Method}

This section presents information on the method of the study, data collection tools and data analysis.

\section{Model of the study}

In the study document analysis which is part of the qualitative research methods is employed. It refers to "the analysis of the written documents that include information about the facts to be analysed." (Yildirim \& Simsek, 2018). In the document analysis the first step is to access the documents. Following careful reading of these documents there written materials are analysed. It is followed by the interpretation and evaluation of these documents (Yildirim \& Simsek, 2018). In the field of educational research, document analysis mostly contain the examination of the manuscripts or printed sources (Duffy, 2014).

\section{Data collection tools}

As stated earlier the data of the study are written materials. More specifically the data were collected from the laws, decree laws, regulations and circulars. These documents were accessed through the websites of the official gazette, the ministry of national education and the ministry of the ministry of family and social policies (MFSP).

\section{Data analysis}

The data collected were analysed through the descriptive analysis. The goal of this analysis is to present the findings obtained in a summarized and interpreted manner to the reader, and it also include quotations (Yildirim \& Simsek, 2018). In this context, the legal documents that constituted the data of the study were first described and ordered according to the date of implementation of the legal regulations, taking into account the hierarchy of norms. Then, the related arrangements were analyzed and interpreted through descriptive analysis, and several assumptions were developed based on the results obtained.

\section{Findings}

This section contains the inclusive education in Turkey which takes into consideration the legislative hierarchy of norms. Legal arrangements about the inclusive education in Turkey are presented in Table 1, Table 2 and Tablo 3. Statements about the inclusive education in Turkey are shown in Table 4 and Table 5. Table 6 indicates the headings covered in the regulations. 
Table 1. Laws and decree laws on inclusive education in Turkey

\begin{tabular}{|c|c|c|c|}
\hline Laws & Number & Date & $\begin{array}{l}\text { Related ministerial } \\
\text { body }\end{array}$ \\
\hline $\begin{array}{l}\text { Law on the children in need } \\
\text { of special education }\end{array}$ & 2916 & $\begin{array}{l}12 \text { October } \\
1983\end{array}$ & MONE \\
\hline $\begin{array}{l}\text { Decree law on special } \\
\text { education }\end{array}$ & 573 & $\begin{array}{ll}06 & \text { June } \\
1997 & \end{array}$ & MONE \\
\hline Law on disabled individuals & 5378 & $\begin{array}{ll}01 & \text { June } \\
2005 & \end{array}$ & MFSP \\
\hline
\end{tabular}

As can be seen in Table 1 there are two laws on children in need of special education. One of them is about the MONE and the other is about the MFSP. Table 1 also indicates that there is also a decree law on this subject which is about the MONE.

Table 2. Regulations designing the inclusive education in Turkish

\begin{tabular}{|c|c|c|c|}
\hline Regulation & Number & Date & $\begin{array}{l}\text { Related } \\
\text { ministry }\end{array}$ \\
\hline Regulation on the special schools & 18790 & 23 June 1985 & MONE \\
\hline $\begin{array}{l}\text { Regulation on education of } \\
\text { mentally handicapped children }\end{array}$ & 21262 & 22 June 1992 & MONE \\
\hline $\begin{array}{l}\text { Regulation on special educational } \\
\text { services }\end{array}$ & 23937 & 18 January 2000 & MONE \\
\hline $\begin{array}{l}\text { Guidance and psychological } \\
\text { services regulation }\end{array}$ & 24376 & 17 April 2001 & MONE \\
\hline $\begin{array}{l}\text { Regulation on special educational } \\
\text { services }\end{array}$ & 26184 & 31 May 2006 & MONE \\
\hline Regulation on guidance services & 30236 & $\begin{array}{l}10 \text { November } \\
2017\end{array}$ & MONE \\
\hline $\begin{array}{l}\text { Regulation on special educational } \\
\text { services }\end{array}$ & 30471 & 07 July 2018 & MONE \\
\hline
\end{tabular}

Table 2 indicates that seven regulations came into effect which were developed by the MONE between 1985 and 2018 to organize the inclusive education in Turkey. 
Table 3. Information on the circulars regulating the inclusive education in

Turkey

\begin{tabular}{|c|c|c|}
\hline Circular & Publication date & $\begin{array}{l}\text { Related } \\
\text { ministry }\end{array}$ \\
\hline $\begin{array}{l}\text { Circular on the pre-school education of } \\
\text { the children in need of special education }\end{array}$ & $\begin{array}{l}21 \quad \text { December } \\
1987\end{array}$ & MONE \\
\hline $\begin{array}{l}\text { Circular on the inclusive education of } \\
\text { the children in need of special needs }\end{array}$ & 20 April 1988 & MONE \\
\hline Inclusive education practices & $\begin{array}{ll}09 & \text { February } \\
2004 & \end{array}$ & MONE \\
\hline Circular on inclusive education practices & $\begin{array}{l}02 \text { September } \\
2008\end{array}$ & MONE \\
\hline $\begin{array}{l}\text { Circular on the widespread inclusive } \\
\text { education at the level of pre-school } \\
\text { education }\end{array}$ & 24 August 2009 & MONE \\
\hline $\begin{array}{l}\text { Circular on the commencement of } \\
\text { support training room }\end{array}$ & 18 May 2015 & MONE \\
\hline Circular on inclusive education practices & $\begin{array}{l}17 \text { September } \\
2017\end{array}$ & MONE \\
\hline
\end{tabular}

As can be seen in Table 3 the MONE developed a total of seven circulars to organize the inclusive education between 1987 and 2017.

Table 4. Statements on the inclusive education covered in the related laws and decree laws

\begin{tabular}{lll}
\hline Law & Article & Statements \\
$\begin{array}{l}\text { Law on the children } \\
\text { in need of special } \\
\text { education }\end{array}$ & $\begin{array}{l}\text { Necessary measures are taken to educate } \\
\text { children in need of special education, } \\
\text { whose conditions and characteristics are } \\
\text { appropriate, among their normal peers at } \\
\text { schools and educational institutions which } \\
\text { are originally opened for the education of } \\
\text { normal children. }\end{array}$ \\
Law on disabled 15 & $\begin{array}{l}\text { Disabled people can benefit from lifelong } \\
\text { education without discrimination on the } \\
\text { individuals } \\
\text { basis of equality, in the environments } \\
\text { integrated with their environment taking } \\
\text { into account their special circumstances } \\
\text { and differences. In the general education } \\
\text { system, integrative education plans are } \\
\text { provided to enable disabled people to } \\
\text { receive education at all levels. }\end{array}$ \\
&
\end{tabular}




\begin{tabular}{|c|c|c|}
\hline \multirow{4}{*}{$\begin{array}{l}\text { Decree law on } \\
\text { special education }\end{array}$} & $3-c$ & $\begin{array}{l}\text { Inclusive education refers to educational } \\
\text { environments developed to enable } \\
\text { individuals who require special education } \\
\text { to interact with other individuals and to } \\
\text { achieve their educational objectives at the } \\
\text { highest level. }\end{array}$ \\
\hline & 4-d & $\begin{array}{l}\text { Priority is given to individuals who need } \\
\text { special education to be educated with other } \\
\text { individuals by making adaptations in terms } \\
\text { of the goals, content and teaching } \\
\text { processes and by taking into account their } \\
\text { educational performance. }\end{array}$ \\
\hline & 12 & $\begin{array}{l}\text { The education of individuals who require } \\
\text { special education is carried out to enable } \\
\text { them to be educated with their peers at } \\
\text { schools and institutions of all types and } \\
\text { levels, using appropriate methods and } \\
\text { techniques in accordance with the } \\
\text { individual education plans developed in } \\
\text { advance. }\end{array}$ \\
\hline & 13 & $\begin{array}{l}\text { The education of students who require } \\
\text { special education, who should be educated } \\
\text { at a separate school or institution with their } \\
\text { peers with similar disabilities, is organized } \\
\text { with appropriate inclusiveness models and } \\
\text { is continued at special education schools } \\
\text { and institutions. }\end{array}$ \\
\hline
\end{tabular}

Table 4 indicates the number of the articles in the related laws and decree laws and the statements and definitions about inclusive education given under these articles. As can be seen in Table 4 the decree on special education includes more and more comprehensive regulations about inclusive education. 
Table 5. Statements on the inclusive education covered in the related regulations

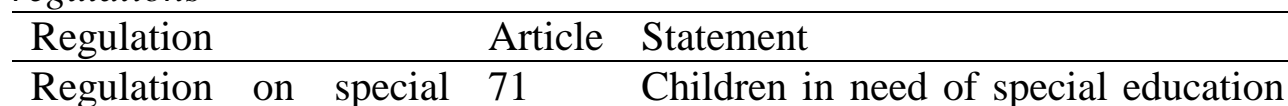
education schools

MONE regulation of the 4 educational activities of disabled children are sent to the classrooms to be opened in the school as a support for the students with special needs in cases where a special class cannot be opened in formal and private primary and secondary schools, high schools and equivalent schools.

Inclusive education refers to the educational program in which children with intellectual disabilities continue education and training with their peers at regular schools.

As a result of the examination carried out by the Guidance and Research

70 Center Directorates, the education of the children who are determined to be at the level of trainable is carried out by putting them in regular classes at primary schools if a sufficient number of students cannot be found.

In education and training of these

71 students the " Educable Children Primary School Program" is followed.

72 In inclusive education there can be only one student with special education in one class at the school. This may be two under compulsory situations.

75 School administrators are responsible for providing necessary steps to offer the needed educational setting for these students to be educated with their peers through inclusive education.

76 The School's Guidance Services Offices and the Guidance teachers who work there provide the necessary guidance activities for both inclusive and special class students. 
Regulation on special 4-d,67 Inclusive education: It refers to education services (2000) special education practices where individuals who require special education are provided with support education services during their formal and private pre-school, primary education, secondary education and their training at non-formal education institutions with their peers without disabilities.

68 Principles of the activities of education through inclusion

69 Criteria about the activities of education through inclusion

$70 \quad$ Full time inclusive education activities

71 Part time inclusive education activities

72 Tasks and responsibilities in inclusive education activities

(Cont.)

\begin{tabular}{lll}
\hline Regulation & Article & Statement \\
\hline Guidance and Psychological & $32-1$ & Duties of the Department of
\end{tabular}

Services Regulation (2001) Special Education Services

The department organizes various in-service training activities and conferences that increase the knowledge and skills of the staff working at special education institutions and the staff of schools implementing inclusive programs.

\section{0-j Duties of Psychological} Counselor

If there is any student requiring inclusive education or if there is any inclusive educaton at the school or mainstreaming education, it provides the necessary guidance and psychological counseling services to the students and their 
Regulation on special education services (2006)

Regulation on guidance 34-m services (2017)

Regulation on special education practices (2018) parents in cooperation with the guidance and research center.

\section{Inclusive education}

Inclusive education is provided

23 (1) to the individuals who need special education, support and educational services together with their peers at pre-school institutions, primary, secondary and non-formal education institutions regardless of being public or and private.

23 (2) Topics to be taken into consideration in inclusive education practices

24(1) Evaluation of student achievement

\section{Tasks of guidance teachers}

They observe the development of mainstreaming students who are trained in the support education room. They guide teachers in this regard.

4-ö Education practices through inclusion / integration are those which are provided in order to ensure that individuals with special education needs interact with other individuals of all types and levels and achieve their educational objectives at the highest level and which are offered full-time or part-time in classes.

(Cont.)

Regulation Article Statement




Regulation on
special
education
services
$(2018)$

\section{Education through inclusion / integration}

(1) Individuals with special educational needs can continue their education at all types and levels through integration / integration in line with the Special Education Evaluation Report.

(2) Individuals with special educational needs can continue their education with their peers in the

22 (1) same class in a full-time manner through inclusion / integration or in special education classes in a part-time manner.

(3) In special education schools where pre-school education, primary education or vocational and technical education programs are delivered, education can be provided through integration / integration.

(4) at the schools where education is delivered through integration / integration it is compulsory that a unit for the IEP should be formed.

(5) Cooperation is made between the IEP development unit and the Student Behavior Evaluation Board and the Award and Discipline Board in regard to the decisions to be taken regarding the students who continue their education through inclusiveness / integration.

23 (1) (1) Full time inclusiveness / integration education $\mathrm{a}, \mathrm{b}, \mathrm{c}$, activities

ç, d

24 (1) (1) Evaluation of student achievement in full time $\mathrm{a}, \mathrm{b}, \mathrm{c}$, inclusiveness / integration education activities ç, d, e, $\mathrm{f}$

25(1) (1) Support education rooms

$\mathrm{a}, \mathrm{b}, \mathrm{c}$,

ç, d, e,

$\mathrm{f}, \mathrm{g}, \breve{\mathrm{g}}$

Table 5 shows the related articles of the regulations about the inclusive education and the related statements and definitions. As can be seen in Table 5 the regulations about the inclusive education become much more detailed from the earliest one to the recent ones. 
Table 6. Circulars published and the regulations covered by these circulars

Circular Regulation

Circular on the pre-school education of children with need of special education (1987)

Ensuring that children in need of special education are educated through inclusive education in formal and private kindergartens and classrooms by the rate of $1 / 10$

Circular on the inclusive Issues to be considered in regard to the education of children with special needs in regular classrooms (1988) education of students with intellectual Inclusive education practices (2004)

disabilities who can be trained in regular classes

The measures taken to ensure that students in inclusive education are able to complete their compulsory education and enjoy the most of their education and training rights.

Circular on inclusive education Measures for students who need to be practices (2008) educated through inclusion education

Circular on the widespread inclusive education at the level of pre-school education

Providing an effective inclusive education for children who are found suitable for inclusive education in the preschool period within the project

Circular on inclusive education practices (2017)

Measures for students who need to be Circular on the commencement of support rooms educated through inclusion education

It is compulsory to establish a support training room at the schools or institutions where students with special education and special talent students are educated within the scope of inclusive education practices.

As can be seen in Table 6 the goal of circulars is to make the topics and necessary steps about the inclusive education activities clear.

\section{Discusson and Conclusion}

One of the significant advances in this regard is the law on children with need of special education numbered 2916 which came into effect in 1983. Akcamete (1998) states that this law and the related regulations guided the inclusive education activities of the period. One of the most significant articles in this law is as follows: "It is essential to educate children in need of special education, whose situation and characteristics are appropriate, with their peers with regular developmental characteristics. Ensuring that the disabled 
and their peers are educated together as much as possible is important in terms of learning to live together." This provision of the law was a turning point in terms of inclusive education in Turkey. Because children with special needs studying in different educational environments until that date had an opportunity to receive education with their peers with this alternative education model.

In 1997 a decree law on special education was passed which is numbered 573. Through this decree law pre-school education was made compulsory to the children with special needs. It also set the standards of special education at the levels of primary education, secondary education, higher education and general education. Sucuoglu and Kargin (2010) state that this decree law on special education numbered 573 is the most comprehensive legal regulation in Turkey in relation to the children with special needs, and it has very similar points to the Education for All Handicapped Children Act which came into effect in the USA in 1975. The Public Law 94-142 and the Education for All Handicapped Children Act modified the general education system and allowed that disabled students can be educated with their peers as much as possible (Gable \& Hendrickson, 2000). Although the law on children with need of special education dated 1983 emphasized the inclusive education for the first time, it also states that necessary steps should be taken to make it possible for children with special needs to be educated with their peers. However, the decree law on special education numbered 573 requires that education of children with special needs with their peers should be prioritized and that the individualized education plans should be developed for this purpose. In addition, it is seen that inclusive education environments are regarded not only as an environment in which children with special needs are educated with their peers who do not have special needs, but also as educational environments developed to achieve educational objectives at the highest level. It is also stated in the decree law that appropriate integration models for the education of children with special needs will be adopted and implemented at special education schools and institutions. These statements indicate the expanded the rights of children with special needs to education.

Another significant law in this regard is the law on disabled individuals which secured the rights of the disabled individuals. Its 15 . article entitled education and training includes the details of the rights of children with special needs to get education. This law is an important legal regulation in terms of combating discrimination and supporting equality. In the law, it is clearly emphasized that the right to education of disabled people cannot be prevented for any reason, and that equal education opportunities should be provided to disabled people in an integrated environment with their non-disabled peers, taking into account their special circumstances and differences. It is also very significant for the inclusive education. Liasidou (2013) argues that inclusive 
education is an internationally mandatory policy phenomenon that includes effective educational approaches and strategies to respond to the distinct needs of students and envisages the right to qualified education of all students. Inclusive education reforms are an endless quest to promote more social and fair ways of pedagogical thinking and acting to create schools and communities that value and respect human diversity (Barton 1997). Therefore, the law on disabled individuals is a significant attempt not to discriminate the children with special needs in educational settings and to make it possible for them to enjoy their educational rights. In the consitution of the republic of Turkey the 42. article states noone can be deprived of the right to education and learning and that primary education is compulsory and free of charge for all citizens and is delivered at public schools.

The right to education is a right based on equality and whose subject is all individuals. The declarations and contracts developed by the United Nations are of great importance in exercising this right. The Salamanca Statement and Framework for Action in Special Needs Education and the United Nations Convention on the Rights of Persons with Disabilities have the goal of "education for all" and emphasize the inclusive education which guide the currect educational policies on inclusive education. The Salamanca Statement and Framework for Action in Special Needs Education provides an efficient legal framework for the activities in inclusive education. The major goal of this statement is to develop a comprehensive educational approach (which include all) and to implement the goal of "education for all" (Dede, 1996). The decree law numbered 573 on special education came into effect three years after the Salamanca statement and created a significant reform in Turkey on inclusive education. The situation can be interpreted as Turkey's development of policies regarding the fundamental rights and freedoms based on the international declarations and conventions.

In Turkey it is the responsibility of the ministry of national education (MONE) to provide equal educational opportunities to children with special needs and to make it possible for them to use their right to be education. To this end, the MONE has issued several regulations on various dates so that individuals with special needs can enjoy their educational rights. The review of the regulations indicates that the understanding of inclusive education as only educating children with special needs with their peers is not the sole basis of the related policies and that the scope of the inclusive education has been widened. In the early regulations inclusive education was mostly understood as the education of the children with special needs with their peers whereas in the recent regulations several points of inclusive education have been emphasized, including its principles, criteria, models, individualized education plans and support education rooms. It indicates that inclusive education is considered to be a multidimensional activity and that the needs of 
the children with special needs are totally taken into consideration. It is gratifying that the rights regarding the education of children benefiting from inclusive education have been brought and the provisions regarding the use of these rights have been introduced. It can be argued that in Turkey inclusive education level is sufficient in terms of legal framework. However, it is not enough in that the implementation of these laws and regulations should also be considered. Research dealing with inclusive education practices at various levels of education, including pres-school, primary school, secondary school and high school indicates that there are some problems in practice (AkdemirOkta, 2008; Anilan \& Kayacan, 2015; Atici, 2014; Babaoglan \& Yilmaz, 2010; Batu \& K1rcaaliİftar, 2011; Bilen, 2007; Cuhadar, 2006; Demir \& Usta, 2019; Deniz \& Coban, 2019; Diken \& Sucuoglu, 1999; Eriskin, Kurac \& Ertugrul, 2012; Gok \& Erbas, 2011; Guleryuz, 2014; Guzel, 2014; KamenAkkoyun, 2007; Kargin, Acarlar \& Sucuoglu, 2005; 2003; K1s, 2013; Nay1r \& Karaman-Kepenekci, 2013; Olcay Gul \& Vuran, 2015; Ozengi, 2009; Sadioglu, 2011; Sarac \& Colak, 2012; Sucuoglu, Bakkaloglu, Işcen-Karasu, Demir \& Akalin, 2014; Sekercioglu, 2010; Tasdemir \& Ozbesler, 2017; Turhan, 2007; Yazicioglu, 2019; Yilmaz, 2015; Yilmaz \& Batu, 2016; Yonter, 2009; Zeybek, 2015).

As can be seen above there have been different circulars about inclusive education at different time preriods and with different content. The circular is defined as an official document sent to the concerned public bodies to guide the implementation of the regulations. Circulars are developed based on a certain regulation (Sevgili Gencay, 2014). The findings indicate that it remains valid in Turkey, and circulars are issued following the publication of the related regulations. For instance, following the regulation on the special education schools dates 1985 a circular entitles the circular on the pre-school education of children with need of special education was issued two years later and then the other were passed. The publication of the circular on the preschool education of children with need of special education is very significant for inclusive education activities in Turkey in that one of its articles is about ensuring that children in need of special education are educated through inclusive education in formal and private kindergartens and classrooms by the rate of 1/10. It made it possible for these children to have pre-school education and for inclusive education to be much more comprehensive.

Another significant regulation is the one which initiated the support education rooms at schools. Because such rooms are environments include special equipment and materials in order to ensure that children with special needs receive the highest level of education. McNamara (1989) states that many countries have issued guidance on how to use these rooms and how to spend time there. In addition, the quality and type of training provided in the support education room determine the success of inclusive education 
(Thurlow, Ysseldyke, Grader \& Algozzine, 1983). Therefore, the publication of such a regulation by the ministry of national education is a reflection of the development of inclusive education in Turkey. In other words, inclusive education was just a conceptual term in the law dated 1983, but over time it is considered to be a right of the children with special needs and the legal framework has been shaped depending on their needs.

As a result, in order to allow the children with special needs to study in general education schools there have been comprehensive legal regulations in Turkey. Especially in the last years, the legal regulations on inclusive education have enabled children with special needs to enjoy their right to education equally and freely like other individuals. In the next process, it is necessary to constantly monitor the inclusion practices in the country, to expand the right to access education as much as possible and to maintain an understanding based on the principle of equality.

\section{References:}

1. Akdemir Okta, D. (2008). Determination of special education services provided to students with hearing impairment and classroom teachers attending inclusive classes (Master's thesis). Retrieved from Higher Education Council National Thesis Center. (Thesis Number: 220921)

2. Akcamete, G. (1998). Special education. S. Eripek. (Broadcast preparation). Turkey in the Special Education (p.p.197-207). Eskisehir: Anadolu University Publishing.

3. Anilan, H., \& Kayacan, G. (2015). The fact of inclusive education through the perspective of class teachers. Bartin University Journal of Education, Special Issue, 74-90.

4. Artiles, A., \& Dyson, A. (2005). Inclusive education in the globalization age. The promise of comparative cultural-historical analysis. In D. Mitchell (Ed.), Contextualising inclusive education (pp. 37-62). Oxfordshire, England: Routledge.

5. Atici, R. (2014). Difficulties of mainstreaming students in school life. Turkish Studies - International Periodical for the Languages, Literature and History of Turkish or Turkic. 9 (5), 279-291.

6. Babaoglan, E., \& Yilmaz, S. (2010). Adequacy of classroom teachers in inclusive education. Kastamonu Education Journal 18(2), 345-354.

7. Barton, L. (1997). 'Inclusive education: Romantic, subversive or realistic?'. International Journal of Inclusive Education, 1(3), 231242.

8. Batu, S., \& Kircaali-Iftar, G. (2011). Inclusive. Ankara: Kok Publising.

9. Bilen, E. (2007). Primary school teacher's opinions about the problems they are facing during the integration activies and their 
solution proposals. (Master's thesis). Retrieved from Higher Education Council National Thesis Center. (Thesis Number: 211466)

10. Constitution of Republic of Turkey. (1982). T. C. Official newspaper, (17344), 18 October 1982, 1-64.

11. Cuhadar, Y. (2006). Determining the opinions of classroom teachers and administrators regarding the preparation, implementation, monitoring and evaluation of individualized education programs for students who are subject to inclusive education in primary education 1-5 grades. (Master's thesis). Retrieved from Higher Education Council National Thesis Center. (Thesis Number: 187138).

12. Daniels, H., \& Garner, P. (1999). Introduction. In H. D. P. Garner (Ed.), World yearbook of education 1999: Inclusive education (pp. 110). London: Kogan Page.

13. Dede, s. (1996). Salamanca Statement About Special Education. Journal of Special Education, 2 (2), 91- 94.

14. Decree Law on Special Education. (1997). T. C. Official Newspaper, (23011), 6 June 1997, 7-14.

15. Demir, E., \& Usta, M. (2019). Opinions of classroom teachers for inclusive education: The case of Karaman Province. International Karamanoglu Mehmet Bey Journal of Educational Research, 1(2), 8098.

16. Deniz, E., \& Coban, A. (2019). Teachers' views on inclusive education. Electronic Journal of Social Sciences, 18(70), 734-761.

17. Diken, İ. H., \& Sucuoglu, B. (1999). Comparison of the attitudes of classroom teachers with and without mentally handicapped children in the class towards the inclusion of mentally handicapped children. Journal of Special Education, 2(3), 25-39.

18. Duffy, B. (2014). The analysis of documentary evidence. In J. Bell (Eds.), Doing your research project: A guide for first-time researchers (pp. 125-140). UK: McGraw-Hill Education.

19. Eripek, S. (2005). Mental deficiency. Ankara: Kok Publising.

20. Eriskin, A., Kurac, S., \& Ertugrul, Y. (2012). Evaluation of the views of classroom teachers on inclusive practices. Journal of Education and Social Sciences, 41(193), 200-213.

21. Gable, R.A., \& Hendrickson, J. M. (2000). Teaching All the Students: A Mandate for Educators. In J.S. Choate (Eds.). Successful Inclusive Teaching, Proven Ways to Detect and Correct Special Needs, (pp. 217). Boston: Allyn \& Bacon.

22. Gok, G. \& Erbas, D. (2011). Views and suggestions of preschool education teachers about inclusive education. International Journal of Early Childhood Special Education, 3(1), 66-87. 
23. Guidance and Psychological Services Regulation. (2001). T. C. Official Newspaper, (24376), 17 April 2001.

24. Guidance Services Regulation. (2017). T. C. Official Newspaper, (30236), 10 November 2017.

25. Guleryuz, B. (2014). Determination of the opinions of classroom teachers and prospective teacher candidates on inclusive education (Master Thesis). Bülent Ecevit University, Institute of Social Sciences,

26. Guzel, N. (2014). Problems the classroom teachers who have mainstreamed students in their classes face (Beykoz district example) (Master's thesis). Retrieved from Higher Education Council National Thesis Center. (Thesis Number:355918)

27. Kamen Akkoyun, A. (2007). Opinions related to mainstreaming of staff members who work in rams.( Master's thesis). Retrieved from Higher Education Council National Thesis Center. (Thesis Number:211309)

28. Kargin, T., Acarlar, F., \& Sucuoglu, B. (2005). Determining the opinions of teachers, administrators and parents about inclusive practices. Ankara University Faculty of Educational Sciences Journal of Special Education, 4(2), 55-76.

29. Kearney, A. (2011). Exclusion from and with in school: Issues and solutions. Netherlands: Sense Publishers.

30. K1s, H. (2013). Guidance counselors and special education teachers views about the resource room special education support services. (Master's thesis). Retrieved from Higher Education Council National Thesis Center. (Thesis Number:336326 )

31. Law on The Children in Need of Special Education. (1983). T. C. Official Newspaper, (18192), 12 October 1983, 2-10.

32. Law on Disabled Individuals. (2005). T. C. Official Newspaper, (25868), 1 July 2005.

33. Liasidou, A. (2013). 'Intersectional understandings of disability and implications for a social justice reform agenda in education policy and practice'. Disability \& Society, 28(3), 299-312.

34. Loreman, T., Deppeler, J., \& Harvey, D. (2011). Inclusive education: Supporting diversity in the classroom. Crows Nest, NSW: Allen and Unwin

35. McNamara, B. E. (1989). The resourceroom: A guide for special educator. New York: State University of NYPress.

36. Ministry of National Education (2014). National Education Statistics Formal Education 2014-2015. Retrieved from http://sgb.meb.gov.tr/istatistik/meb_istatistikleri_orgun_egitim_2014 _2015.pdf 
37. Ministry of National Education (2018). National Education Statistics Formal Education 2017-2018. Retrieved from http://sgb.meb.gov.tr/meb_iys_dosyalar/2018_09/06123056_meb_ist atistikleri_orgun_egitim_2017_2018.pdf.

38. Nayır, F., \& Karaman-Kepenekci, Y. (2013). Opinions of classroom teachers on the rights of inclusive students. Journal of Educational Sciences Research, 3 (2), 69-89.

39. OECD (1995). Integrating Students With Special Needs Into Mainstream Schools. Paris: OECD Publications.

40. Olcay Gul, S.,\& Vuran, S. ( 2015). Children with Special Needs' Opinions and Problems about Inclusive Practices. Education and Science, 40(180), 169-195.

41. Ozengi, S. S. (2009). To determine the opinions and suggestions of school counselors about inclusion practices at the elementary schools where they work in Eskisehir. (Master's thesis). Retrieved from Higher Education Council National Thesis Center. (Thesis Number: 249401)

42. Regulation on Special Educational Services. (2000). T. C. Official Newspaper, (23937), 18 January 2000, 418-467.

43. Regulation on Special Educational Services. (2006). T. C. Official Newspaper, (26184), 31 May 2006.

44. Regulation on Special Educational Services. (2018). T. C. Official Newspaper, (30471), 7 July 2018.

45. Regulation on The Special Schools. (1985). T. C. Official Newspaper, (18953), 9 December 1985, 4-23.

46. Regulation on Education of Mentally Handicapped Children. (1992). T.C. Official Newspaper, (21262), 22 June 1992, 1-29.

47. Sadioglu, Ö., Batu, E. S., \& Bilgin A. (2012). Opinions of classroom teachers about the inclusion of students with special needs. Journal of Uludăg University Faculty of Education, 25(2), 399-432.

48. Sarac, T. \& Colak, A. (2012). Opinions and suggestions of primary school teachers regarding the problems they face during the mainstreaming practices. Mersin University Faculty of Education Journal, 8(1), 13-28.

49. Sevgili Gencay, F. D. (2014). The place of anonymous regulatory processes in the hierarchy of norms. Journal of Ankara University Faculty of Law, 63(2), 397-417.

50. Sucuoglu, B., Bakkaloglu, H., İscen-Karasu, F., Demir, S., \& Akalin, S. (2014). Preschool teachers' knowledge levels about inclusion. Educational Sciences in Theory and Practice, 14(4), 1467-1485. doi: 10.12738/estp.2014.4.2078

51. Sucuoglu, B., Kargin, T. (2010). Inclusive Practices in Primary Education. Ankara. Kök Publishing House 
52. Sekercioglu, B. (2010). Primary school branch teachers 'opinions about problems theyare facin during inclusive education. (Master's thesis). Retrieved from Higher Education Council National Thesis Center. (Thesis Number:279695)

53. Thurlow, M. L., Ysseldyke, J. E., Grader, J. L., \& Algozzine, B. (1983). What's special about the special education resource room for the learning disabled student? Learning Disability Quarterly, 6, 283288. doi:10.2307/1510439

54. Tasdemir, H., \& Ozbesler, C. (2017). Evaluation of the problems faced by children attending inclusive education in the perspective of social work practices in the school environment. International Journal of Social Research, 10 (49), 498-507.

55. Turhan, C. (2007). Opinions of students with normal development attending primary school where inclusive practice is applied (Master's thesis). Retrieved from Higher Education Council National Thesis Center. (Thesis Number:210096)

56. UNESCO. (2005). Guidelines for Inclusion: Ensuring access to education for all. Paris: UNESCO, p.13.

57. UNESCO. (2012). Education: Addressing exclusion. Retrieved November 13, 2014, from http://www.unesco.org/new/en/education/themes/strengtheningeducation-systems/inclusiveeducation/

58. World Health Organization. (2011). World report on disability, Retrieved from http://www.who.int/disabilities/world_report/2011/en/

59. Yazicioglu, T. (2019). Analysis of Anatolian high school teachers' views on inclusive education through metaphor analysis. OPUS International Journal of Community Research, 14(20), 394-420.

60. Yazicioglu, T. (2020). Determining the views of school principals about the legal arrangements about inclusive education. Bolu Abant Izzet Baysal Faculty of Education Journal, 20(1), 168-181.

61. Yilmaz, E. (2015). Opinions of teachers in an elementary school about inclusive practices (Master's thesis). Retrieved from Higher Education Council National Thesis Center. (Thesis Number:407803)

62. Yilmaz, E., \& Batu, E. S. (2016). Opinions of primary school teachers from different branches about Individualized Education Program, legal regulations and inclusion practices. Ankara University Faculty of Educational Sciences Special Education Journal, 17(3), 247-268.

63. Yilmaz, E., \& Melekoglu, M.A. (2018). The situation in law and practice of inclusive education be evaluated in the context of Turkey and Europe. Osmangazi Journal of Education Research, 5(1), 1-17.

64. Yonter, S. (2009). Opinions of the teachers of inclusive classes in primary schools about instructional adaptations in mathematics for 
students with intellectual disabilities. (Master's thesis). Retrieved from Higher Education Council National Thesis Center. (Thesis Number:241755)

65. Zeybek, O. (2015). Opinions and suggestions of English teachers in primary schools regarding inclusive practices (Master's thesis). Retrieved from Higher Education Council National Thesis Center. (Thesis Number:388883)

66. Yildirim, A., \& Simsek, H. (2018). Qualitative research methods in the social sciences. Ankara: Seckin Publishing. 